\title{
Secessionists vs. Unionists in Catalonia: Mood, Emotional Profiles and Beliefs about Secession Perspectives in Two Confronted Communities
}

\author{
Josep Maria Oller ${ }^{1}$, Albert Satorra ${ }^{2}$, Adolf Tobeña ${ }^{3^{*}}$ \\ ${ }^{1}$ Department of Genetics, Microbiology and Statistics, University of Barcelona, Barcelona, Spain \\ ${ }^{2}$ Department of Economics and Business, Universitat Pompeu Fabra and Barcelona-GSE, Barcelona, Spain \\ ${ }^{3}$ Department of Psychiatry and Forensic Medicine, Institute of Neurosciences, Universitat Autònoma Barcelona, \\ Bellaterra Campus, Barcelona, Spain \\ Email: *adolf.tobena@uab.cat
}

How to cite this paper: Oller, J. M., Satorra, A., \& Tobeña, A. (2019). Secessionists vs. Unionists in Catalonia: Mood, Emotional Profiles and Beliefs about Secession Perspectives in Two Confronted Communities. Psychology, 10, 336-357.

https://doi.org/10.4236/psych.2019.103024

Received: December 17, 2018

Accepted: February 18, 2019

Published: February 21, 2019

Copyright $\odot 2019$ by author(s) and Scientific Research Publishing Inc. This work is licensed under the Creative Commons Attribution International License (CC BY 4.0).

http://creativecommons.org/licenses/by/4.0/

(c) (i) Open Access

\begin{abstract}
Political tensions created by Catalonian secessionism within Spain are unsettled one year after the failed proclamation of independence at $27^{\text {th }}$ October 2017. A big segment of citizens (38\% - 48\% of the region population) supports secession, but there is another portion of citizenry, of similar size, that has resisted secessionist aspirations. Secessionism acquired forceful impetus along the last decade, wining consecutive regional elections and two (illegal) consultations about self-determination. A rise of activism, however, showed by unionists both at street demonstrations and at the last Regional election, consolidated a draw within a deeply polarized and divided society. We present an analysis of survey data that distinguish prevalent mood and emotion profiles among unionist vs. secessionist segments. Despite their protracted and unsuccessful venture, secessionists felt much less tired and confused than unionists, and they referred to be much less fearful and more hopeful about political and economic future. We link those distinctive feelings and disparate beliefs about current difficulties with a cognitive distortion noticeable only among secessionists, about the real magnitude of their force. We discuss these findings connecting such cognitive and affective profiles with features of a compounded ethno-cultural frontier based mainly on habitual language (Catalan vs. Spanish) and family-descent origins that have probably worked as the principal alignment vector. This social cleavage might function as a fracture line for extremist aggravations of a serious political conflict within the European Union.
\end{abstract}




\section{Keywords}

Secessionism, Catalonia, Spain, Ethno-Cultures, Emotions, Belief Distortions, Linguistic Borders, Political Conflict, Political Passion, Nationalism

\section{Introduction}

The surge of an ambitious secessionist movement that gained wide support to the point of repeatedly winning the majority at Catalonian Parliament was contemplated with surprise because it appeared within a rich and advanced European region, without intolerable grievances from Spain or deep internal litigations. A profusion of interpretations (Amat, 2015, 2017; Barceló-Soler, 2013; Boylan, 2015; Crameri, 2014, 2015; Elliot, 2018; Griffiths et al., 2015; Minder, 2017; Luque, 2018; Morel, 2018), tried to explain the sudden appearance and endurance of a movement that has demonstrated great strength for a decade. Those diagnoses focused mainly on economic and socio-political issues from Southern European recent hardships: a long and deep economic recession during the preceding years, irritation with corruption and malfunctioning of Spanish institutions and parties, fragility of the European Union, passivity of Central Government combined with impulsiveness and frenzy ambitions of regional elites. These factors probably contributed in various ways though the quandary of why they had uniquely combined within a single place, while other Spanish and European regions with comparable problems were devoid of such tensions, remained unanswered.

The outbreak of demands for conquering Catalonian independence had a quickly growing momentum from 2010 onwards, and there is wide consensus that psychological factors played a relevant contribution to the social effervescence. Several analyses have emphasized, in this regard, the decisive role played by institutional propaganda and unremitting social pressure. An intensive indoctrination effort from TV channels, broadcasting stations and other media/net platforms related directly (or indirectly) to the Regional Government, was combined with a persistent activism campaign devoted to monopolize all public areas, within the Region. This was achieved by the stubborn presence of secessionist flags, emblems and signs everywhere (Crameri, 2014, 2015; OEC Group, 2017; Minder, 2017; Tobeña, 2017a; Elliot, 2018; Morel, 2018). These campaigns had obvious goals: attaining a political majority for secessionists and keeping the non-secessionist segment of Catalan citizenry intimidated.

Two successive Regional elections (Sept. 2015; Dec. 2017); two illegal but successfully enacted pseudo-referendums of self-determination in which only the secessionists went to the poll stations ( $9^{\text {th }}$ Nov., 2014; $1^{\text {st }}$ Oct. 2017), and a long series of systematic surveys both by C.E.O. (the official survey agency of the Regional Government) ${ }^{1}$, and C.I.S (the official survey agency of the Central Gov${ }^{1}$ CEO (Centre d'Estudis d'Opinió, http://ceo.gencat.cat/). 
ernment $)^{2}$, had showed the existence of a neat political division among Catalan citizens on the issue of secession from Spain. The fragmentation depicted a society divided in two halves: secessionists and non-secessionists. Across the period 2015-2018, the direct question "Do you want Catalonia to be an independent state?" (C.E.O. series of "Political Barometers"), had received "YES" answers, with percentages oscillating between $40.8 \%$ and $48.7 \%$; "NO" answers, oscillating between $42.4 \%$ and $53.9 \%$, plus $5 \%$ to $10 \%$ remnants of "DON'T KNOW" answers. These surveys are iterated three times per year, at least, using large enough samples.

At Sept. $27^{\text {th }}, 2015$, regional elections, with a turnout of $77.4 \%$, secessionist parties got $1,957,348$ votes ( $47.8 \%$ of all votes). Non-secessionist forces got a total of $2,110,586$ votes (51.28\% of all votes). A narrow margin of 150.000 votes separated unionists from secessionists. The 21th Dec. 2017 elections were called by the Spanish Government as a way to discontinue the suspension of the Autonomy Rule, dictated two months before, as a response to the "Independence Declaration" on $27^{\text {th }}$ Oct. 2017. Results offered again the landscape of a tightly divided society: the turnout reached an historical mark of $79.1 \%$; secessionist parties obtained 2,079,330 votes (47.33\%), whereas the non-secessionist parties attained $2,227,421$ votes $(50.71 \%)$. The same margin of 150,000 votes separated unionists from secessionists ${ }^{3}$.

These figures show that around 3 million of Catalans (from an electoral census of around 5.5 million, within a population of more than 7 million), did not join the secessionist venture. The main part of such big fraction of the citizenry has familial, affective and economic links with Spain. They are very heterogeneous though they predominate in towns on the industrial areas of Barcelona and Tarragona's conurbations, as well as in many other suburban neighborhoods across the network of medium-sized villages within the region. They had remained mostly silent and expectant along the secessionist surge and this contributed to the perception that they will accept, with resignation, a separatist victory. The weeks that preceded the "Independence Declaration" on $27^{\text {th }}$ Oct. 2017, witnessed, however, the awakening of unionist's activism amid the escalating tensions that pervaded all scenarios of social and economic life within the region. They deployed big street demonstrations at downtown Barcelona that competed with the gigantic ones that secessionists had mounted repeatedly (Coll, Molina, \& Arias-Maldonado, 2018; Crameri, 2014, 2015; Minder, 2017; Morel, 2018; Tobeña, 2017b).

Marí-Klose $(2015,2018)$ had described a crucial social cleavage that separates the two main communities who coexist in Catalonia: 1) "Catalans", native citizens by long family descent plus individuals who have been wholly assimilated, both personally and culturally, vs. 2) "CatSpanish", the long-settled but ${ }^{2}$ CIS (Centro de Investigaciones Sociológicas, http://www.cis.es/cis/opencms/ES/index.html). ${ }^{3}$ The leading formation at the Parliament was, however, for the first time in decades, a unionist party: "Citizens" with 1,109,732 voters (25.5\%) and 36 seats, although the majority went, once more, to the secessionists parties (70 Parliament seats, from a total of 135) due to an over-representation to the rural areas. 
non-assimilated migrants from other Spanish regions plus more recent waves of Latin-American migrants. The first ones use Catalan language in all professional and living domains, whereas the second ones prefer Spanish, though most of them have also a good instrumental knowledge of Catalan language because it is the mandatory first language at primary schools and for most of secondary education as well ${ }^{4}$. Bertomeus (2018a) detected an increasing tendency towards political polarization between these two populations by studying the evolution of voting behaviour, in relation to the familial language, during the years of the secessionist wave. Using data from CEO Barometers after the four Regional elections celebrated in the period 2010-2017, he found that Catalan-speaking citizens substantially augmented their support to the secessionist parties, whereas Spanish-speaking citizens increased their support to unionist parties in quite synchronic though divergent shifts. $22 \%$ of Catalan-speaking citizens (their habitual language) voted at 2010 for non-secessionist parties, compared to less than $10 \%$ at 2017. At the other side of the linguistic frontier, one third of Spanish-speaking citizens (habitual language) opted for nationalist-regionalist parties at 2010, but that percentage had dropped to $15 \%$ on the last regional election (Dec. 2017). A remnant of $8 \%$ of voters at the middle of the linguistic frontier-using both languages indistinctively-, divided their votes between secessionist and unionist parties without changes along the period. Such tendency towards a strong polarization about secession rooted on the main linguistic divide had been previously showed by OEC Group (2017), comparing data from other CEO Barometers.

Llaneras (2017) added several socioeconomic factors that helped to distinguish cleavages separating unionists from secessionists. He departed from CEO Barometer of June-July 2017: 1500 personal interviews on stratified sample of the region population. Secession appealed mostly to native Catalans: independence approval was higher on citizens born in Catalonia and with at least one parent born there, and such preference was maximal (75\%) fort those with a long family descent within the region. Conversely, among citizens coming from abroad or other Spanish regions, and born in Catalonia but from migrant parents, secession was not attractive at all. These findings replicated, in fact, similar analyses on Sept. 2015 regional elections: the same family divisions predicted either voting for secessionist or non-secessionist parties. The divide between secessionists and unionists depended also on income levels. Citizens with highest incomes and those who answered "we live comfortably", to questions about their finances were the ones that supported secession. On the contrary, most people with the lowest salaries and those reporting "many economic difficulties" were against secession. Familial origin and income levels were inter-correlated: monthly incomes were much higher in native Catalans than in citizens from other Spanish regions or from abroad (Llaneras, 2017).

${ }^{4}$ See: "Usos lingüístics de la població de Catalunya: enquesta 2013, Generalitat de Catalunya: Departament de Cultura,

http://llengua.gencat.cat/web/.content/documents/publicacions/altres/arxius/eulp2013_fullet.pdf. 
All these findings highlighted the existence a compounded social cleavage between two neighboring communities that has probably worked as the main breaking line for the deep political fracture created by the forceful secessionist movement (Tobeña, 2017b, 2018). The divide has not arrived at the threshold of an open violent conflict, though tensions were high during autumn of 2017 and they still subsist, though attenuated, while the political situation remains on an apparently unsolvable standstill. All kind of frictions appear at different social scenarios and keep nowadays confronted two communities who enjoyed a long tradition of tolerant and convivial relationships (Amat, 2017; Elliot, 2018). There are worries, in fact, that such a divide may lead to inter-group confrontations that would carry the dangerous and hateful ingredients that appear in societies containing unsealed ethno-cultural frontiers (Horowitz, 2001; Lustick et al., 2004; Sorens, 2005; Qvortrup, 2014).

Given all that, we reasoned that it could be useful to get a portrait of the affective and emotional profiles of these two confronted communities, in addition to their extant beliefs about the political situation and their perspectives about the future. We expected to extract hints that would permit to establish useful psychological connections between affective states and prevalent cognitive appraisals at both sides of a hot and deep political divide. By accruing a map of affective and belief differences between secessionists and unionists we hoped to expand the landscape of attributes that characterizes the divide among Catalans vs. Catspanish fractions: a separation or fracture line that reflects mainly recent political tensions despite being based on long-established group alignments that depend on language and family origins. We finally wanted to contribute with necessarily transient but objective data to the analyses of a serious and unsolved secession conflict at the heart of the European Union.

\section{Methods}

We used data obtained in a survey developed by the enterprise GAD $-3^{5}$, during March 2018, through phone calls either to landline or mobile phones of people residing in Catalonia over 18 years old. This survey included questions about mood and emotions linked to the secessionist conflict, among many other standard socioeconomic features, like gender, age group, profession, labour situation or familiar language. Specifically, there was a single question asking subjects if they would support the secession of Catalonia in a referendum. The sample size was of $n=1000$ surveyed individuals across the region, weighted posteriorly for age-group and gender to avoid or reduce sample biases. The standard deviation of the percentage corresponding to any binary question was less than $1.58 \%$.

First of all, we focused our attention in the variable "secession support" as this variable allows the partition of the population in three groups determined by the answers of the surveyed subjects in a plausible referendum about secession: "Yes", "No" or "DK/NA" (don't know, and non-available answers). We were in-

${ }^{5} \mathrm{GAD}-3$ (https://www.gad3.com/). 
terested in finding the variables that best determined the variable of "secessionist support", the variable Q07 of the survey (see the Appendix). In a first analysis of the described data set, we focused on the marginal stochastic dependence of psychological variables of mood, emotional profiles and beliefs (a total of up to 25 variables) with the "secessionist support" variable in its three categories: YES/NO and DK/NA. The YES and NO categories defined the secessionist and unionist segments, respectively, of the population. With the variable "secession support" and each one of these other 25 variables, we made a contingency table, which allowed to calculate a standard chi-square test, $\chi^{2}$, its $p$-value and also a standardised contingence coefficient of Pearson ${ }^{6}, C$, (see Pearson, 1904). This coefficient is a measure of the stochastic dependence between the considered pair of variables and is less dependent on sample size and the number of levels of the categorical variables considered than $\chi^{2}$ statistics. It was used previously in Oller and Satorra (2017) as a tool to define a political toxicity index. The results are presented in a table (Table 1) and a lollipop graphic (Figure 1).

In order to describe the secessionist versus the unionist population segments we supply also bar charts of several variables, in particular those variables

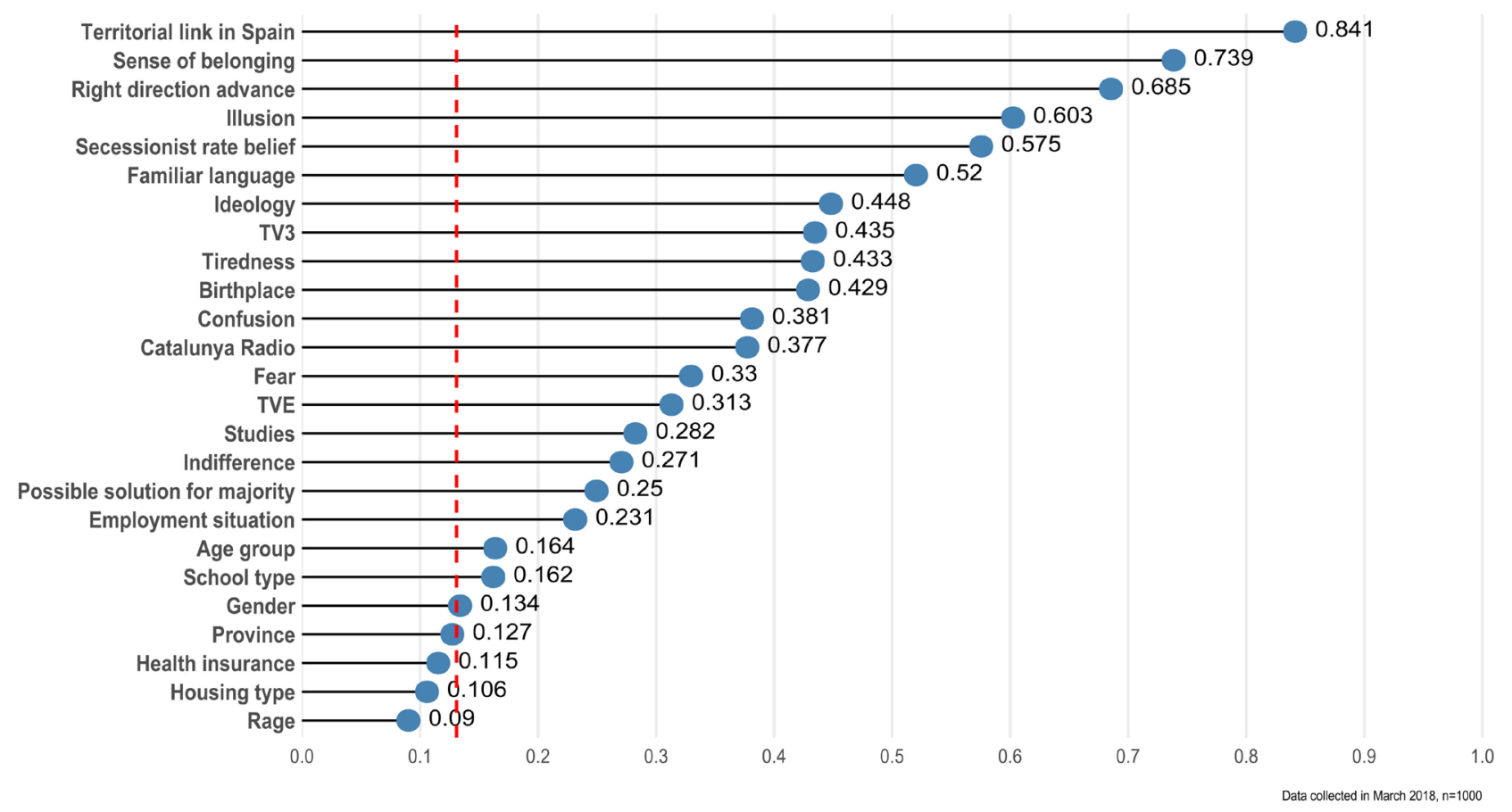

Figure 1. Differences between Catalan secessionists and unionists on 25 categorical variables of the survey. Numerical values and length of the bar correspond to the contingency coefficient $C$ reported at Table 1 . Variables are sorted by their $C$ values. All the variables with bullets on the right of the red line of the graph distinguished significantly ( $5 \%$ level) between both groups of citizens.

\footnotetext{
${ }^{6}$ The standardised coefficient of contingency, $C$, is defined as $C=\sqrt{\frac{m \chi^{2}}{(m-1)\left(\chi^{2}+n\right)}}$ Where $n$ is the total sample size, in the present case $n=1000$, and $m=\min \{k, q\} \quad$ where $k$ are the number of segments corresponding to one categorical variable, for example "secession support", with $k=3$ and $q>1$ are the number of segments corresponding to the other categorical variable considered.
} 
Table 1. Associations of support to secession with each one of the remaining 25 variables, denoting mood, beliefs and habits, from a GAD-3 survey, March 2018, sample size $n=$ 1000 , Catalonian residents. From top to down, the variables have been ordered in descending order of the magnitude of association measured by the contingency coefficient $C$. Variables below the red line are not significant at the 5\% level. TV3: regional TV public channel; Catalunya Radio: main public broadcast station; TVE: main state TV channel.

\begin{tabular}{|c|c|c|c|c|}
\hline Variable & $x^{2}$ & d.f. & $p$-value & $C$ \\
\hline Territorial link & 894.1 & 8 & $<<10^{-8}$ & 0.841 \\
\hline Sense of belonging & 571.4 & 10 & $<<10^{-8}$ & 0.739 \\
\hline Right direction advance & 456.1 & 6 & $<<10^{-8}$ & 0.685 \\
\hline Feelings of illusion & 319.3 & 4 & $<<10^{-8}$ & 0.603 \\
\hline Secessionist rate belief & 283.3 & 12 & $<<10^{-8}$ & 0.575 \\
\hline Familiar language & 220.2 & 6 & $<<10^{-8}$ & 0.520 \\
\hline Ideology & 154.6 & 10 & $<<10^{-8}$ & 0.448 \\
\hline TV3 & 144.1 & 4 & $<<10^{-8}$ & 0.435 \\
\hline Tiredness feelings & 142.7 & 4 & $<<10^{-8}$ & 0.433 \\
\hline Birthplace & 139.7 & 4 & $<<10^{-8}$ & 0.429 \\
\hline Confusion feelings & 107.3 & 4 & $<<10^{-8}$ & 0.381 \\
\hline Catalunya Radio & 104.9 & 4 & $<<10^{-8}$ & 0.377 \\
\hline Fear feelings & 78.1 & 4 & $<<10^{-8}$ & 0.330 \\
\hline TVE & 69.9 & 4 & $<<10^{-8}$ & 0.313 \\
\hline Studies & 56.2 & 8 & $<10^{-8}$ & 0.282 \\
\hline In difference feelings & 51.4 & 4 & $<10^{-8}$ & 0.271 \\
\hline Possible solution for majority & 43.3 & 4 & $<10^{-8}$ & 0.250 \\
\hline Employment situation & 37.1 & 16 & 0.0021 & 0.232 \\
\hline Age group & 18.2 & 6 & 0.0058 & 0.164 \\
\hline School class & 17.8 & 6 & 0.0067 & 0.162 \\
\hline Gender & 9.1 & 2 & 0.0108 & 0.134 \\
\hline Province & 10.9 & 6 & 0.0906 & 0.127 \\
\hline Health insurance & 9.0 & 4 & 0.0620 & 0.115 \\
\hline Housing type & 7.5 & 10 & 0.6744 & 0.106 \\
\hline Rage feelings & 5.5 & 4 & 0.2442 & 0.090 \\
\hline
\end{tabular}

connected to some basic emotional and affective states: confusion, illusion, tiredness, rage, indifference and fear. A mosaic chart and other graphs were also obtained to make clear the difference between secessionists and unionists with respect to the perception of the secession support. In that case we know, by the findings of periodic CEO-CIS surveys that the secession support has been always strictly less than $50 \%$ and on the other hand the electoral support obtained by secessionist parties at several recent elections always has been less than $37.4 \%$ of the census as can be checked from the official electoral data. An analysis of this 
perception by groups of ages is also presented. The relationship between secession support and familiar language, born place, social media consumption and studies is also briefly explicitly examined, coinciding this survey results with findings of many other previous ones.

$\underline{\text { Ethics. }}$. As stated, the data for this research came from a phone survey made by the polling private institute GAD3 (https://www.gad3.com), complying with the full legal Spanish requirements and restrictions to conduct sociological studies about voting behavior and political opinion, and in accordance to the ESOMAR International Code on Market, Opinion and Social Research and Data Analytics. The totally anonymous poll was conducted by live interviewers, by phone: $50 \%$ of the sample was landline phone and the other $50 \%$ mobile phones. Contacted individuals were free to reject answering the survey and there were no questions regarding personal identities of responders, who had full warrants that their responses would be treated as untraceable numerical scores within a unique sample and preserving full anonymity. Present researchers were allowed access to the datasheets containing the raw scores of the survey under totally blind conditions concerning the identity of surveyed participants, who cannot be traced through any procedure. All the statistical analyses included in this paper fulfilled, in addition, the conditions established by the Ethical Commissions of the University of Barcelona, Pompeu Fabra University and the Autonomous University of Barcelona for treatment of human data, when their original source are surveys made by official agencies or private firms under specific external regulations with due guarantees. So, an ethics approval was not required for this secondary analysis of the data, as per the authors' Institutions and national regulations.

\section{Results}

\section{- Variables associated with secessionist support}

The global scores of the variable "secession support" in the present survey were: "Yes" (40.8\%), "No" (53.4\%) and "DK/NA" (5.8\%). These values were consistent with the results of many previous surveys and with the support to secessionist parties at the last Regional elections, December $21^{\text {th }}, 2017$, where JxCat $+\mathrm{ERC}+\mathrm{CUP}^{7}$ secessionist formations had a $37.4 \%$ over the overall electoral census (including residents outside Catalonia), and $38.8 \%$ if we only consider the electoral census of people with present residence in Catalonia.

We studied first the differences between secessionists and unionists detected in the survey with respect to their answers to other 25 questions, with the DK/NA option included as single category in the analysis. With "secession support" variable and each one of the rest we built contingency tables, which allowed to calculate standard chi-square test, $\chi^{2}$, to analyse the stochastic dependence of each variable and "secession support". Moreover, $p$-value and the standardised contingence coefficient of Pearson, $C$, for each variable were also com-

${ }^{7}$ JxCAT: Junts per Catalunya; ERC: Esquerra Republicana de Catalunya; CUP: Candidatures d'Unitat Popular. 
puted. The results are summarized in Table 1. Most variables exhibited a high stochastic dependence with "secession support". They appear ordered by the magnitude of their dependence as measured by the contingency coefficient index $C$, and over the red line of the graph are those variables that showed a clear significant association ( $p$-value below 5\%) with "support to secession".

After a Bonferroni correction due to the large number (25) of variables under scrutiny for significance, "gender" could be discarded, because its degree of dependence was small, while "school type", "age groups" or "employment situation" showed a slight dependence. It is remarkable that, despite the limited sample size of the survey, all other variables under scrutiny showed a clear association (stochastic dependence) with "secession". In addition, these contrasts allowed to conclude that there was no enough evidence that secessionists and unionists behaved differently with respect the variables "gender", "province", "health insurance", "housing type" and "rage feelings".

The "lollipop" of Figure 1 shows a summary of the degree of association of the variable "support to secession" with each one of the remaining 25 variables. The highest association (contingency coefficient $C=0.841$ ) was with variable (Q06) "Territorial link in Spain" and the lowest with the variable (Q04d) "Rage Feelings $(C=0.09)$.

Next step was to inspect the psychological variables that were highly associated (Table 1 and Figure 1) with the variable that defined the secessionist and the unionist groups. Figure 2 display the distinctive profiles showed by unionists and secessionists concerning mood and feelings aroused by the secessionist challenge, as well as beliefs about the prospects and evolution of the political confrontation.

As a reinforcement of the key results of Figure 2, a further treatment is displayed at Figure 3. The graph shows the percentages of "Yes" responses in each of the 8 mood or belief topics for the unionist ( $\mathrm{X}$ axis) and secessionist ( $\mathrm{Y}$ axis) groups. For each question, the estimated population percentage in both groups is the vertex of the cross. The amplitude of two arms of the cross (horizontal and vertical) are the $95 \%$ confidence intervals of the estimated percentages (horizontal arm for unionist percentages, and vertical arm for secessionist percentages) ${ }^{8}$. If both groups, unionist and secessionist, had the same percentage of "Yes" responses, then the centre of the cross would lie on the diagonal line (the "equal response line", within the graph). As the cross arms are 95\% confidence intervals, not touching the $45^{\circ}$ line implies rejection, at $5 \%$ level, of the null hypothesis of equality of the responses to that question by both groups. "Rage" was the only sentiment that was not significantly different between groups: the cross touches the diagonal line. For the other feelings and beliefs, the hypothesis of no difference across the two groups was rejected at the 5\% level. "Illusion" and "the conflict advances in the right direction" were on the top left of the graph, indicating that they were very unequal between groups, with the secessionists having

${ }^{8}$ These $95 \%$ confidence intervals were obtained using the bootstrap method based on 1000 bootstrap replicates, attending the weighing of the sample. 

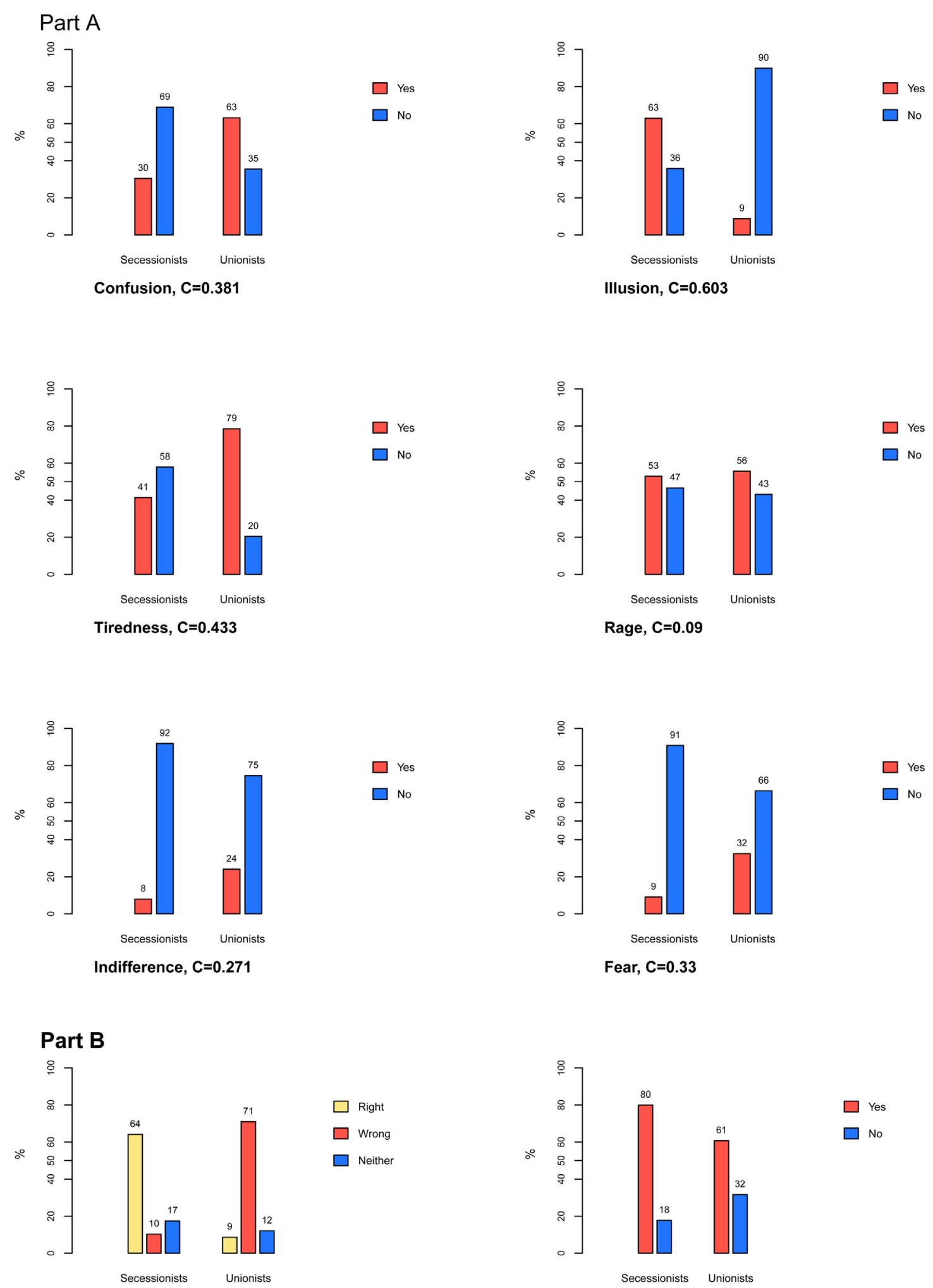

Right direction advance, $\mathrm{C}=0.685$

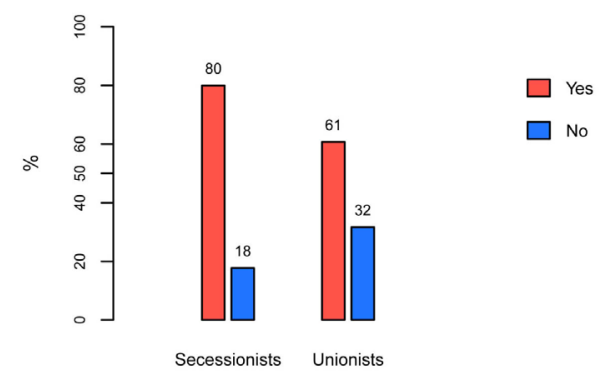

Possible solution for majority, $\mathrm{C}=0.25$

Figure 2. Part A: Mood-emotional results among secessionists and unionists, groups defined for their respective support vs. rejection for secession. Part B: Beliefs about prospects of secessionist conflict. Degrees of agreement with "advances on the right direction" or "the existence of a plausible solution for the majority" and their relations with "secessionist support". To simplify the reading of the graph, the category of the DK/NA has been excluded. 
$\mathrm{XY}$-comparative graph of responses

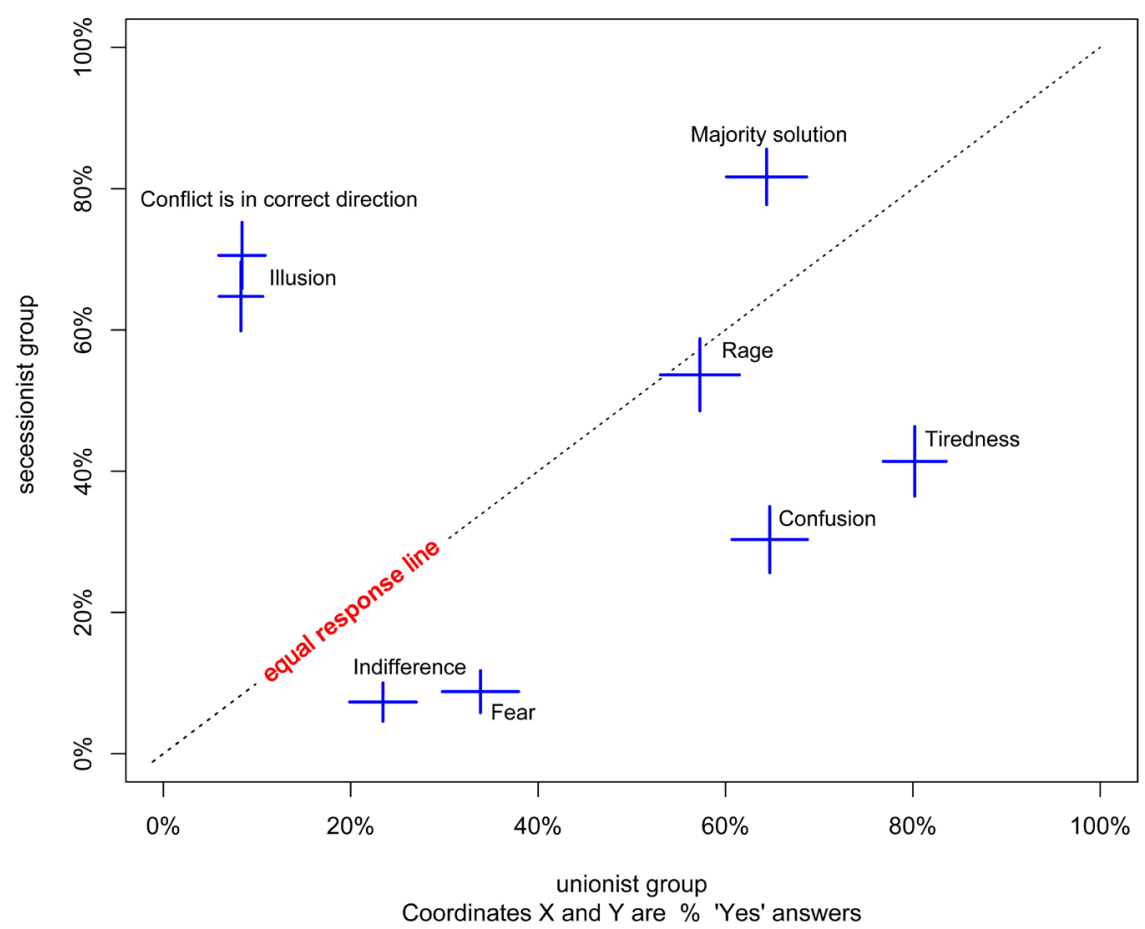

Figure 3. Summary of mood-feelings and beliefs about the prospects of the secessionist conflict that distinguish secessionists from unionists.

a much higher "Yes" percentages. "Tiredness" and "Confusion" were also very unequal among groups, but with the unionist group having much larger "Yes" percentages on these feelings. Finally, "Fear" feelings had higher "Yes" percentages in the unionists. For details of the wording of the questions for each of the feelings and beliefs, see the Appendix.

\section{- Distortions on perceptions about secessionism support}

One variable that distinguished very clearly the secessionist and unionist groups was "Secessionist rate belief" (at Figure 1 it occupies the 5th highest position for differences across both groups). This is the variable Q08 of the Appendix, with the question worded as: "What percentage of Catalans do you think is in favor of independence?' The response options to this question are listed in the first column of the table at Figure 4, the other columns of the table showing the \% of responses on the different responses by both groups. It can be seen, for example, that while only $0.3 \%$ of secessionist believe the secessionist strength is $40 \%$ or less, the $28.3 \%$ of unionists gave that response. The table and mosaic plot at Figure 4 illustrate the differential perceptions of secessionist and unionist groups regarding the strength of the secessionist movement. They show the remarkable fact that while the vast majority of secessionists (except 15.7\%: the blue box, at the mosaic) believed that the strength of the secessionists was greater than $50 \%$ (a belief that is not real: contradicted by repeated surveys and election results), the majority of the unionists had the belief that the size of secessionism support was lower than 50\% (a belief that is concordant with reality). The last 


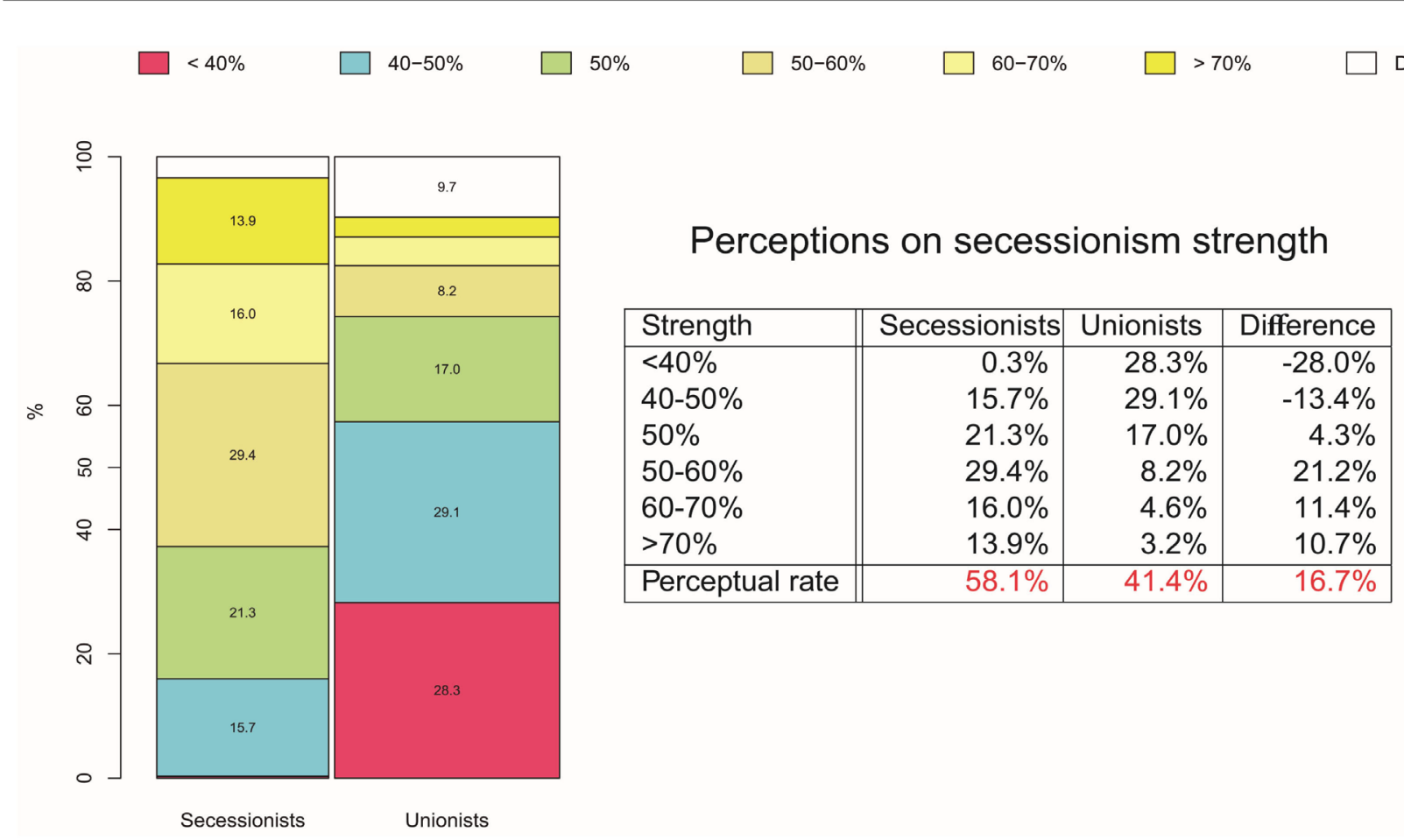

Figure 4. Difference between secessionists and unionists on the perception of secessionist strength. Each row of the side-table shows, for each group, the \% of responses on the specific category strength listed in the first column, with the last row being the average perceived secessionist strength (average calculated using mark classes and excluding DK/NA). The mosaic plot represents the rows of the table (except the last row) as piled boxes with area proportional to the estimated \% of the category in the population (the basis of the rectangle are proportional to the size of the group).

row of the table shows the "average perception" which were very different in both groups. These perceptual differences about the average strength in each group were obtained using their mark classes, since the variables had been categorized, excluding DK/NA.

Next, we compared the estimation of the secessionist strength in each group with the support obtained by the secessionist parties $\left(J_{x} C a t+E R C+C U P\right)$, in the last Regional elections, Dec. 2017, which was, approximately, $38.8 \%$ of the electoral census of citizens living within the region. The data shows a clear distortion about reality by the secessionist group when asked about the strength of secessionism (variable Q08 of the questionnaire, see the Appendix): secessionists tended to overestimate their strength. We compared that belief with the reality shown both in the election results reported above and at repeated CEO surveys. The difference between the estimate and the "true" value of $38.8 \%$, can be clearly seen at Figure 5: the secessionist group exhibited the largest cognitive distortion, while the unionist group provided a reasonable average perception of the secessionist strength.

Furthermore, the data on Figure 5 allows a comparison between secessionist and the unionists groups in terms of wrong (or right) perceptions about the secessionist strength, considering as a right perception to estimate the size of secessionist support as less than $50 \%$ and wrong the opposite: greater or equal $50 \%$. This is so, because secession rate strength estimated through CEO repeated 

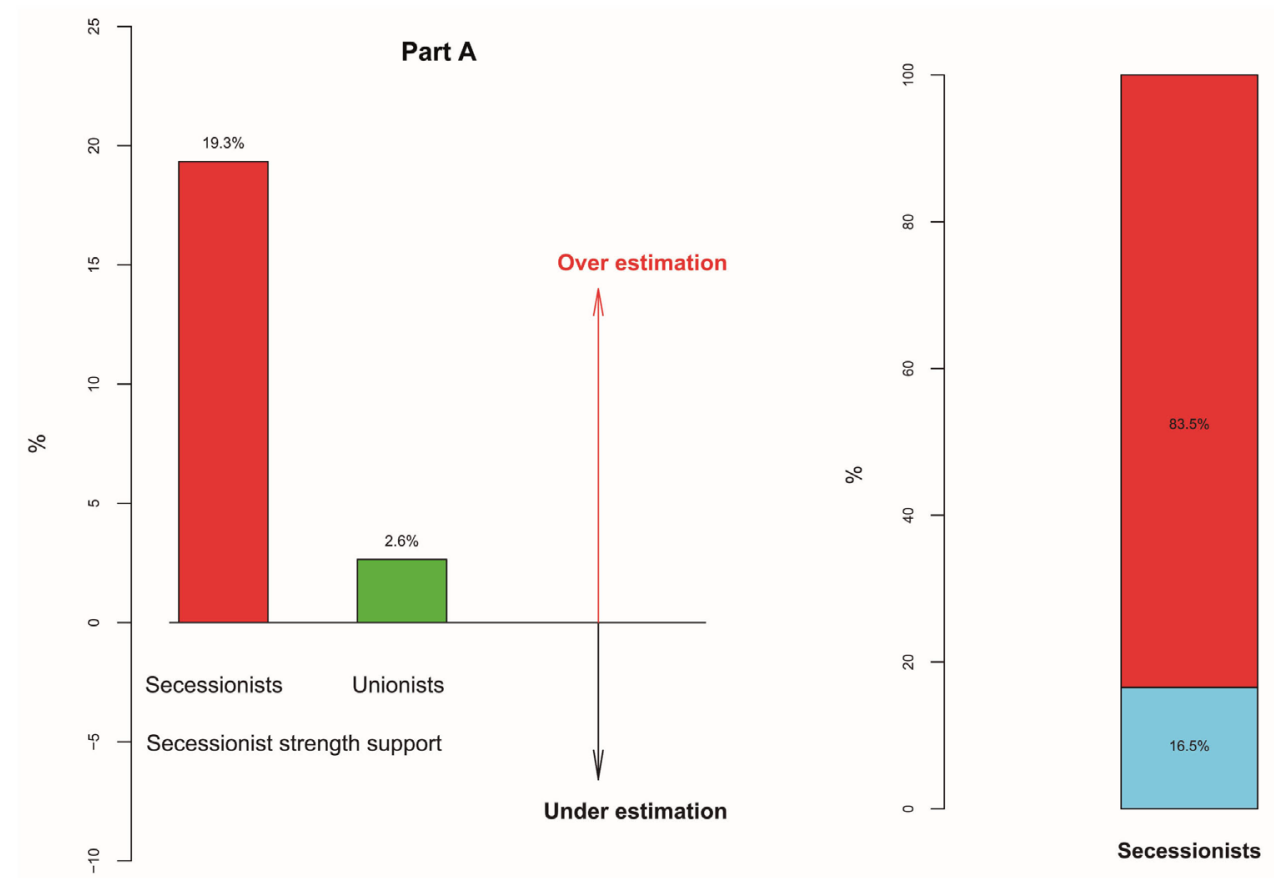

Part B

Figure 5. Part A: Perceptual distortion about secessionist strength. The secessionist group showed a clear perception distortion of its own strength. Part B: In red, the percentages of people which overestimated the secessionist strength; in blue, the percentages of people with right perceptions about secessionist strength.

surveys (official statistics) oscillates a bit, but always under 50\%, and voting support for secessionist parties was 38.8\% at last regional elections Dec. 21, 2017, as pointed out before (using the electoral census considering only citizens living in the region).

Curiously, the distorted perception of the strength of secessionism appeared also when comparing young (less than 30 years) versus older people (greater or equal 30 years), as can be seen at Table 2 . The youngest group exhibited a higher perceptual distortion about the magnitude of secessionism. With the same criteria as used before, considering less than $50 \%$ as a right perception to estimate secessionist size and wrong the opposite, the percentage of young people with a right perception were only $22.5 \%$, and those with a wrong one $77.5 \%$.

\section{- Identity variables and secessionism}

Another variable that was highly related to secessionist support was the "sense of belonging" (At Figure 1, Table 1 it ranked on the 2th position of the difference among both groups). It is remarkable that the unionist segment presents predominantly mixed feelings of belonging (Catspanish), while the secessionist group had feelings of belonging more often exclusively Catalan (Figure 6). The relationships between "secession support" and "familiar language" or "birth place" were also very strong, as in previous studies (Oller \& Satorra, 2017; OEC Group, 2017). A slight relationship appeared also with the variable "Studies" (educational level), a variable that at Figure 1 occupied the 11th position from the bottom. Analyzing the profiles of both groups for this variable we detected that secessionist had higher percentages of University studies, while the 


$$
\begin{array}{r}
0 \\
0 \\
0 \\
0 \\
0 \\
0 \\
0 \\
0 \\
0 \\
0 \\
0 \\
0 \\
0
\end{array}-
$$

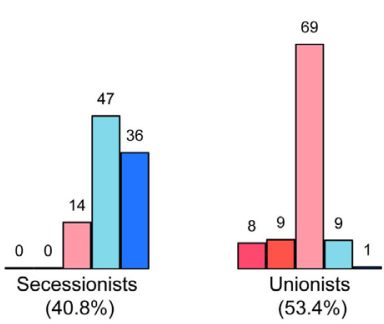

$\square \begin{gathered}\text { Spanish } \\ (4.6 \%)\end{gathered}$

Spa $>$ Cat

$\mathrm{Spa}>\mathrm{Ca}$
$(4.9 \%)$

Spa $=$ Cat
$(45.4 \%)$

Cat $>$ Spa

$(26.3 \%)$

$\square \begin{gathered}\text { Catalan } \\ (15.1 \%)\end{gathered}$

Sense of belonging, $C=0.739$

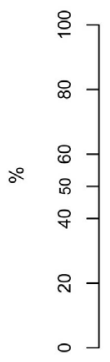
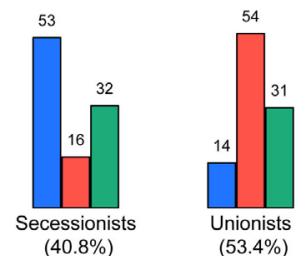

Familiar language, $C=0.52$
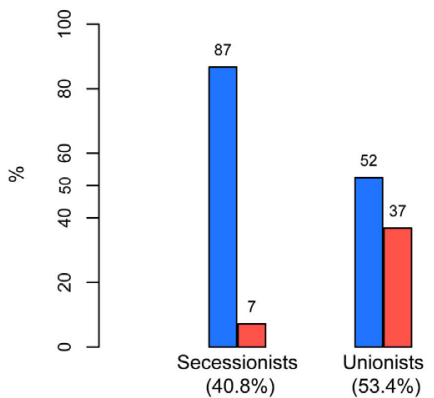

Birthplace, $\mathrm{C}=0.429$

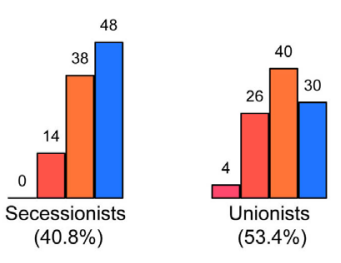

Studies, $\mathbf{C}=0.282$ $\square$ No studies

$(2.2 \%)$

Basic
$(20.9 \%)$

Secondary

(39\%)

Universitary

$(37.8 \%)$

Figure 6. Identity perception (sense of belonging); familiar language (Catalan vs. Spanish), educational levels and birthplace (Catalonia vs. rest of Spain) distributions, in relation with support/reject of secession. See Appendix for the questions.

Table 2. Perceived beliefs about secessionist strength for two age groups. Percentages obtained as in the table of Figure 4. In red, the secessionist support percentage averages were calculated for each group, using mark classes, excluding DK/NA.

\begin{tabular}{cccc}
\hline Strength & $<30$ Years & $\geq 30$ Years & Difference \\
\hline$<40 \%$ & $10.8 \%$ & $16.2 \%$ & $-5.4 \%$ \\
$40 \%-50 \%$ & $11.7 \%$ & $25.5 \%$ & $-13.8 \%$ \\
$50 \%$ & $24.3 \%$ & $18.1 \%$ & $6.2 \%$ \\
$50 \%-60 \%$ & $17.5 \%$ & $17.2 \%$ & $0.3 \%$ \\
$60 \%-70 \%$ & $16.9 \%$ & $8.6 \%$ & $8.3 \%$ \\
$>70 \%$ & $17.3 \%$ & $6.5 \%$ & $10.8 \%$ \\
Perceptual rate & $55.7 \%$ & $48.1 \%$ & $7.6 \%$ \\
\hline
\end{tabular}

highest $\%$ for unionists, were Secondary studies. Further research is needed to discern the sources of these differences between secessionists and unionists on education level. It is well known that level of education (especially, university degrees) is related to social class. The confounding with social class is apparent, as we observed in our data a higher social status of secessionists compared with the unionists.

In this paper we have focused our attention in bivariate associations between moods, beliefs and perceptions about the political situation, with the support for 
secession expressed by unionist and secessionist segments. Most of the associations detected were clearly significant with the sample size used and, additionally, the possible biases of the survey were minimized using weights in a standard way. It's worth reminding that although the present study only reflects a transient portrait of Catalonian citizenry feelings and perceptions at March 2018, several of these variables had also been studied previously, and the results reported here cohere with the ones repeatedly supplied and reported by CEO, particularly the close links between secession support and voting behaviour distributions of secessionists and unionists, across the region, as well as variations and consistency trends at different surveys (Bertomeus, 2018a; Oller \& Satorra, 2017; OEC Group, 2017). The association of secessionist support with other more structural type of variables, such as familiar origin, linguistic, and selective media preferences and socioeconomic levels has been discussed elsewhere and will be subjected to more detailed analyses in another paper.

\section{Discussion}

The abrupt surge, rapid deployment and failed (for the moment) culmination of the recent secessionist attempt at Catalonia were a unique political experiment. It was based on the following ingredients: 1) repeated and gigantic street demonstrations; 2) stubborn and systematic media propaganda; 3 ) overwhelming social pressure by a continuous presence of secessionist symbols everywhere; 4) strong impulse and direction given by a disobedient Regional Government and a disloyal Autonomous Parliament; 5) absence of a clear social majority; 6) successful silencing of the non-secessionist citizenry throughout most of the upsurge. All that arising at one of the richest and more advanced Spanish regions, within democratic context at the heart of the European Union.

The secessionist effervescence was indeed an unexpected, forceful and colourful mass movement that attracted media attention of the whole world, leaving the Spanish Central Government curiously paralyzed for years and the European Union perplexed. The more worrying consequence of that secession venture has been the excavation of a sharp divide of Catalan society into two big and confronted communities. The lack of a clear social majority behind the secessionist attempt opened apprehensions that had been tampered for decades. Close neighbours, colleagues, acquaintances and even friends and families who had shared feelings of belonging to both Catalonia and Spain (in different degrees), as an essential part of their political values, are now deeply divided on the issue of secession and must endure living and working together amid a continuous and unresolved tension that contaminates many aspects of social life (Alvarez, 2018; Amat, 2017; Bertomeus, 2018a; Coll et al., 2018; Luque, 2018; Morel, 2018; Elliot, 2018; Tobeña, 2018).

The findings of this study offer a portrait necessarily transient but very informative of the emotional and affective feelings of these two confronted segments of Catalan society, in addition to their beliefs and prospects for the near future as a political community. The moment when the survey was administered, March 
2018, was peculiar indeed: three months had elapsed after a renovated victory of secessionist parties at the Regional elections of $27^{\text {th }}$ Dec. 2017. However, the formation of a new Regional Government and the closure of Central intervention of the Autonomy Rule were still pending because the majority at the Regional Parliament unsuccessfully tried to reinstate in power those secessionist leaders who had been imprisoned or fled to exile, after the failure of Independence Proclamation at October 2017. Consequently, the political situation had ingredients of a bizarre and tense standstill.

In that peculiar context, our findings clearly show that secessionists felt much less tired and confused than unionists, after a protracted and unsuccessful confrontation; they also said to be much less fearful and had higher illusions and expectations about the future. They were not tired or indifferent after years of campaigns and demonstrations that finished with a strange and "rhetoric-like" proclamation of independence almost devoid of any practical or legal consequence. The culminating weeks of the secessionist attempt led by a rebellious Regional Government, at Set-Oct 2017, contained features, however, that were not rhetoric at all. To give just one example: about 4.500 enterprises moved their main headquarters from Catalonia to several cities around Spain (among them, the major banks and leading financial and industrial firms); and many thousands of millions of Euros were moved by individuals to bank accounts outside Catalonia. At villages and cities near the border with other Spanish regions, there were long lines of Catalan clients, waiting at bank branches to open new accounts and move their savings (Elliot, 2018; Martínez, 2018; Minder, 2017; Morel, 2018).

Despite all that and the not so rare incidents of open tensions at the streets, the present findings show that surveyed secessionists expressed a firm conviction that politics at Catalonia was "moving on the right direction" and that "a plausible and good solution for the majority was at hand", beliefs and hopes that were not shared at all by unionists. Probably that trusting and hopeful certainty about the benefits of continuing with such a polarizing and dividing venture derived from a perceived distortion about the real magnitude of the secessionist field. As our findings clearly show the secessionists seriously misperceived the size of secessionism support and the magnitude of political contenders at the region, a misperception that was only paralleled by the youngest surveyed (by definition, the less politically experienced). Age was not, however, an important variable at most contrasts in the present survey.

It had been noted that the abrupt surge of secessionism, from 2012 onwards, was based on the sudden transformation of a rather mature electorate that had been supporting moderate nationalist parties, for decades, into a body of unmovable and fanatic secessionists (Bertomeus, 2018b). Such unforeseen change was probably due to the harsh competition among secessionist parties to lead the region, with the ensuing activism and relentless propaganda campaigns across media channels and online platforms that were mainly directed to nourish hopes of an achievable, prompt and decisive victory (Amat, 2017; Coll et al., 2018; To- 
beña, 2017a, 2017b; Morel, 2018; Luque, 2018). In support of this, a recent large-scale analysis provided evidence that during the 2017 illegal referendum for Catalonian independence social bots generated and disseminated violent contents aimed mainly at the secessionist field (Stella et al., 2018). Nearly 4 million Twitter posts related to that issue and created by almost 1 million users, were analyzed during two weeks around such event, and the findings showed that automated social hacking contributed to exacerbate the political conflict.

Perhaps the strongest achievement of secessionist activism and propaganda has been the creation of such an intense and moralistic devotion for the goal of secession, to the point of attaining the stubborn, emphatic and mood-enhancing traits of a romantic communal passion (Tobeña, 2017b). Convictions and commitments aroused by that kind of political passion can mirror, to some extent, those characterizing sacred (morally charged) values of devote affiliates to extremist movements (Atran, 2016), for which the first neural substrates have been described (Petrus et al., 2018). Using peripheral physiological indicators Garrett (2018) showed moreover that the degree of moral conviction primes fervent and unyielding political responses.

The strong devotion for secession hardly enticed, however, half of Catalan population because it conveyed obsessive-like and self-glorification ingredients that excluded, by definition, the remaining non-devote citizenry. Secessionists were fully convinced that they deserved a graceful separation from Spain on the bases of a tiny parliamentary majority but lacking a real social majority. This was a curious belief that might derive from the operation of "collective narcissism" (Golec de Zavala et al., 2009). Such attribute rests on the firm conviction about the unique greatness of one's group accompanied by demands of external validation. Those narcissists are not content to be members of a valuable community: they believe that their group worth is not recognised. They demand privileged treatment, not equal rights. Recent findings indicated that "collective narcissism" was implicated in crucial votes: apart from partisanship (Mason, 2018), this trait was the strongest factor predicting Trump's victory at 2016 US presidential election (Golec de Zavala et al., 2017), and it predicted Brexit vote at 2016, as well (Federico \& Golec de Zavala, 2018). It would be necessary to extend these enquiries to Catalan's secessionist and unionist communities.

Fulfilling a dream for reaching full sovereignty through agreed and fully democratic pathways probably requires support from a rather large majority, something above $70 \%$ of people at least. An undisputable fraction of a society who would need also to be affectively engaged with the prospects of the new communal frame and citizenship. If Catalonian secessionism insists in pursuing along the same tracks of unilateral impositions that have characterized the recent, impatient and illegal wave, it will only lead to deepen the existing and worrying fracture between Catalans and Catspanish segments within the region citizenry. A political and affective divide that announces a chronically split and conflictual Catalonia (Bertomeus, 2018a; Elliot, 2018; Luque, 2018; Morel, 2018). This is so because our results confirmed again, in a robust and very consistent 
way, the crucial dependence of support for secession upon ethnocultural and economic divides. Familiar language (Catalan vs. Spanish); type of family descent (Catalan natives vs. long settled migrants from other Spanish regions plus more recently settled from abroad); and educational level (as a proxy of wealth and status), were main predictors for support vs. rejection of secession. These findings help thus to discern the relevant components of a clear cut ethnocultural frontier along which political tensions can be aggravated very easily (Horowitz, 2001; Miley, 2007; Qvortrup, 2014, Marí-Klose, 2015; Llaneras, 2017; Tobeña, 2017a, 2017b; OEC Group, 2017; Bertomeus, 2018a). Such kind of ethno-cultural alignment was illustrated also by the relevance of identity feelings: "sense of belonging" was an important mediator of the gap between secessionists and unionists. The first ones declared an almost exclusive emotional/affective identity link with Catalonia, whereas unionists had more dispersed and mixed communal affects, in which a double attachment with Spain-Catalonia (Catspanish people), clearly predominated.

While writing this paper (Autumn 2018) initial approaches and talks were started between a new left-wing Central Government in Spain and the secessionist Regional Government of Catalonia, which was finally formed at the end of Spring 2018, with all privileges of Home Rule fully reinstated. Nobody knows, however, if something fruitful will evolve from that. Something like a pathway for political reform or agreement that would permit changes in the very disparate mood and expectations about the near future that characterize these strongly entrenched Catalan communities, as we have described. Distinctive moods and beliefs that, while discounting minor and frequent oscillations, we suspect they continue with very similar profiles as shown here.

\section{Acknowledgements}

SCC (Societat Civil Catalana, https://www.societatcivilcatalana.cat/), promoted the GAD-3 Survey which was the basis for the present study and provided full access to the data. GAD3 (https://www.gad3.com) is a polling private institute, one of the most recognized polling firms in Spain and member of ESOMAR and ANEIMO. The survey was done in accordance to the ESOMAR International Code on Market, Opinion and Social Research and Data Analytics. AT work was partially supported by AFOSR-MINERVA FA9550-18-0496 Grant.

\section{Conflicts of Interest}

The authors declare no conflicts of interest regarding the publication of this paper.

\section{References}

Alvarez, J. L. (2018). Els de casa frente a els de for a. El País-Opinión, 15 February, 13.

Amat, J. (2015). El llargprocés: cultura i política a la Catalunya contemporània (1937-2014). Barcelona: Tusquets. 
Amat, J. (2017). La conjura delos irresponsables. Barcelona: Anagrama.

Atran, S. (2016). The Devoted Actor: Unconditional Commitment and Intractable Conflict across Cultures. Current Anthropology, 57, S192-S203. https://doi.org/10.1086/685495

Barceló-Soler, J. (2013). The Battle for Secession: Catalonia versus Spain. Journal of Political Inquiry, 2013, 1-11.

Bertomeus, O. (2018a). ¿Sigue Cataluña siendo “un sol poble”? Agenda Pública, 3, 5.

Bertomeus, O. (2018b). El terratrèmolsilenciós: relleu generacional i transformació del comportament electoral a Catalunya. Vic: Eumo Ed.

Boylan, B. M. (2015). In Pursuit of Independence: The Political Economy of Catalonia's Secessionist Movement. Nations and Nationalism, 21, 761-785. https://doi.org/10.1111/nana.12121

Coll, J., Molina, I., \& Arias-Maldonado, M. (Eds.) (2018). Anatomía del process. Madrid: Debate.

Crameri, K. (2014). Goodbye Spain? The Question of Independence for Catalonia. Eastbourne, UK: Sussex Academic Press.

Crameri, K. (2015). Political Power and Civil Counterpower: The Complex Dynamics of the Catalan Independence Movement. Nationalism and Ethnic Politics, 21, 104-120. https://doi.org/10.1080/13537113.2015.1003491

Elliot, J. H. (2018). Scots and Catalans: Union and Disunion. New Haven: Yale University Press.

Federico, Ch. M., \& Golec de Zavala, A. (2018). Collective Narcissism and the 2016 United States Presidential Vote. Public Opinion Quarterly, 82, 110-121. https://doi.org/10.1093/poq/nfx048

Garrett, K. N. (2018). Fired up by Morality: The Unique Physiological Response Tied to Moral Conviction in Politics. Political Psychology. https://doi.org/10.1111/pops.12527

Golec de Zavala, A., Cichocka, A., Eidelson, R., \& Jayawickreme, N. (2009). Collective Narcissism and Its Social Consequences. Journal of Personality and Social Psychology, 97, 1074-1096. https://doi.org/10.1037/a0016904

Golec de Zavala, A., Guerra, R., \& Simao, C. (2017). The Relationship between the Brexit Vote and Individual Predictors of Prejudice: Collective Narcissism, Right-Wing Authoritarianism and Social Dominance Orientation. Frontiers in Psychology, 8, 2023. https://doi.org/10.3389/fpsyg.2017.02023

Griffiths, R. D., Guillén-Alvarez, P., \& Martínez Coma, F. (2015). Between the Sword and the Wall: Spain's Limited Options for Catalan Secessionism. Nations and Nationalism, 21, 43-61. https://doi.org/10.1111/nana.12102

Horowitz, D. (2001). The Deadly Ethnic Riot. Berkeley, CA: University of California Press.

Llaneras, K. (2017). El apoyo a la independencia tiene raíces económicas y de origen social. El País.

https://politica.elpais.com/politica/2017/09/28/ratio/1506601198_808440.html

Luque, P. (2018). La secesión en los dominios del lobo. Madrid: Catarata.

Lustick, I. S., Miodownik, D., \& Eidelson, R. J. (2004). Secessionism in Multi-Cultural States: Does Sharing Power Prevent or Encourage It? American Political Science Review, 98, 209-229. https://doi.org/10.1017/S0003055404001108

Marí-Klose, P. (2015). Un solo pueblo. El País-Opinión. https://elpais.com/elpais/2015/10/05/opinion/1444046875_755284.html 
Marí-Klose, P. (2018). Cataluña deshilachada: procesos de desintegración de una comunidad imaginada. In J. Coll, I. Molina, \& M. Arias-Maldonado (Eds.), Anatomía del procés (pp. 221-246). Madrid: Debate.

Martínez, G. (2018). 57 días en Piolín. Madrid: Lengua de Trapo.

Mason, L. (2018). Uncivil Agreement: How Politics Became Our Identity. Chicago, IL: University Chicago Press. https://doi.org/10.7208/chicago/9780226524689.001.0001

Miley, T. J. (2007). Against the Thesis of the "Civic Nation": The Case of Catalonia in Contemporary Spain. Nationalism and Ethnic Politics, 13, 1-37. https://doi.org/10.1080/13537110601155734

Minder, R. (2017). The Struggle for Catalonia: Rebel Politics in Spain. London: Hurst and Co.

Morel, S. (2018). En el huracán catalán. Barcelona: Planeta.

OEC Group (2017). La Cataluña immune al procès. SCC, Barcelona, 20th April. https://www.societatcivilcatalana.cat/sites/default/files/docs/La-Cataluna-inmune-vf.pd f

Oller, J. M., \& Satorra, A. (2017). Toward an Index of Political Toxicity. Boletın de Estadistica e Investigacion Operativa, 33, 163-182. http://www.seio.es/BBEIO/BEIOVol33Num2/index.html\#86

Pearson, K. (1904). Mathematical Contributions to the Theory of Evolution. Dulau and Co.

Petrus, C., Hamid, N., Sheikh, H., Ginges, J., Tobeña, A., Davis, R., Vilarroya, O., \& Atran, S. (2018). Neural and Behavioral Correlates of Sacredvalues and Vulnerability to Violent Extremism. Frontiers in Psychology, 9, 2462.

https://doi.org/10.3389/fpsyg.2018.02462

Qvortrup, M. (2014). Referendums and Ethnic Conflict. Philadelphia, PA: University of Pennsylvania Press. https://doi.org/10.9783/9780812209327

Sorens, J. (2005). The Cross-Sectional Determinants of Secessionism in Advanced Democracies. Comparative Political Studies, 38, 304-326.

https://doi.org/10.1177/0010414004272538

Stella, M., Ferrara, E., \& De Domenico, M. (2018). Bots Increase Exposure to Negative and Inflammatory Content in Online Social Systems. PNAS, 115, 12435-12440. https://doi.org/10.1073/pnas.1803470115

Tobeña, A. (2017a). Secessionist Urges in Catalonia: Media Indoctrination and Social Pressure Effects. Psychology, 8, 77-96. https://doi.org/10.4236/psych.2017.81006

Tobeña, A. (2017b). La pasión secesionista: Psicobiología del independentismo. Barcelona: EDLibros.

Tobeña, A. (2018). Entrenched Catalonia: A Secessionist Venture Trapped on a Ethnopolitical Draw. Psychology, 9, 460-471. https://doi.org/10.4236/psych.2018.93028 


\section{Appendix: Questions}

Q01 Gender:

Man 1. Women 2.

Q02 Age:

in years (categorized later: 18 - 29 years, 30 - 44 years, 45 - 64 years, 65 or older).

Q03 To begin with, do you think Catalonia is moving in the right direction or in the wrong direction?

In the right direction 1 . In the wrong direction 2. Neither one nor the other (without reading the option) 3. DK/NA 4.

Q04 And what feelings does the current political situation in Catalonia cause?

\begin{tabular}{cccc}
\hline & Yes & Not & DK/NA \\
\hline Confusion & 1 & 2 & 3 \\
Illusion & 1 & 2 & 3 \\
Tiredness & 1 & 2 & 3 \\
Rage & 1 & 2 & 3 \\
Indifference & 1 & 2 & 3 \\
Fear & 1 & 2 & 3 \\
\hline
\end{tabular}

Q05 Do you think it is possible to find a solution that can satisfy a large majority of Catalans?

Yes 1. No 2. DK/NA 3.

Q06 In any case, do you think Catalonia should be...? (Territorial link in Spain)

A region in Spain 1. An autonomous community in Spain 2. A federal State in Spain 3. An independent State 4. DK 5. NC 6.

Q07 In any case, "do you want Catalonia to be an independent State"? Yes 1. No 2. DK/NA 3.

Q08 What percentage of Catalans do you think is in favour of independence? (categorized)

More than $70 \%$ in favour 1 .Between $60 \%$ and $70 \%$ in favour 2. Between $50 \%$ and $60 \%$ in favour $3.50 \%$ in favour 4 . Between $40 \%$ and $50 \%$ in favour 5 . Less than $40 \%$ in favour 6 . DK/NA 7.

Q09 Which of the following phrases best expresses your identity? You feel... (Sense of belonging)

Only Spanish 1. More Spanish than Catalan 2. As Spanish as Catalan 3 More Catalan than Spanish 4. Only Catalan \%. DK/NA 6.

Q10 Could you tell me which language do you usually use at home? Spanish 1. Catalan 2. Either 3. Other languages 4. DK/NA 5.

Q11 Regarding media, what television channels do you usually see? 


\begin{tabular}{rccc}
\hline & Yes & No & DK/NA \\
\hline TV3 (Public Catalan TV) & 1 & 2 & 3 \\
TVE (Public Spanish TV) & 1 & 2 & 3 \\
\hline
\end{tabular}

Q12 Do you listen the radio station "Catalunya Radio"?

Yes 1. No 2. DK/NA 3.

Q13 Could you tell me your level of education?

Without studies 1 . Primary studies 2 . Secondary studies 3, University studies. DK/NA 5.

Q14 And, your academic background was developed mostly in a: Public school 1. Private school 2. Concerted school 3. DK/NA 4.

Q15 And, what is your current employment situation?

Private sector worker 1. Public sector worker 2. Autonomous/Businessman

3. Retired/Pensioner 4. Unemployed 5. Student 6. Unpaid domestic work 7. Other 8. DK/NA 9.

Q16 And you live in a house:

In property (without pending payments) 1.In property (width pending payments) 2. Rented 3. Assigned 4. Other 5. DK/NA 6.

Q17 Where were you born?

In Catalonia 1. In other Autonomous Community in Spain 2. Outside of Spain 3.

Q18 And with regard to your ideology, how do you consider yourself, rather from the left or rather from the right?

Left 1. Centre left 2. Centre 3. Centre right 4. Right 5. DK/NA 6.

Q19 Do you have medical insurance with any private company?

Yes 1. No 2. DK/NA 3. 